\title{
Variations in Fruit Quality Parameters of Chilli Genotypes during Early and Timely Sown Conditions
}

\author{
Khushpreet Kaur Dhaliwal*, Navita Ghai ${ }^{1}$ and S. K. Jindal ${ }^{2}$ \\ ${ }^{1}$ Department of Botany, ${ }^{2}$ Department of Vegetable Science, Punjab Agricultural University, \\ Ludhiana-141004, India \\ *Corresponding author
}

A B S T R A C T

\section{Keywords \\ Chilli, yield, biochemical parameters, fruit quality}

Article Info

Accepted:

18 May 2020

Available Online:

10 June 2020
The present investigation was planned to evaluate fruit quality parameters in different chilli genotypes. So those, the present identify suitable genotype for early planting. In this study, compare the yield performance along with physiological and biochemical parameters of early and timely sown hot pepper genotypes. On the basis of physiological, biochemical parameters and yield, genotype PL-412 performed best and can be used for breeding programs for chilli production for early season crop.

\section{Introduction}

Chilli (Capsicum annum) is one of the major seasonal spice in India and is consumed in excess of all other spices. India is the largest producer of chillies in the world also their consumption is also highest in India. No country in the world has so much area and production as much as India (Jyothi et al., 2008). Chillies occupied approximately $30 \%$ of the area among spice crops of India (Indian Horticulture Database, 2011). In all over the India huge variations in duration of crop is found. India posses many varieties with different quality factors such as phenotypic characters, pungency and flavour (Asati and Yadav, 2004). Low and high temperature condition affect the size of fruit and seed germination ability. Fruit set and productivity of pepper reduced during periods of high temperature. High temperature frequently occurs after anthesis of chilli pepper and strongly impacts the reproduction and yield.

Capsaicinoids are the compounds that are responsible for the pungency, aroma and flavor of the hot chili peppers. Capsaicin is the most abundant capsaicinoid found in chili peppers (Zahra et al., 2016). It is a compound of no flavour and is accumulated in veins of 
capsicum fruits. Capsaicin is located in vesicle like structures present in epidermal cells of placenta in the pod. Besides it was used in food industry, capsaicin has found its application in pharmaceutical industry as well providing many health benefits and treatment strategies for medical conditions. Capsaicin identifies malignant cell lines and specifically attaches the immortal dividing cancerous cells and retards their growth.

Chilli is also good source of oleoresin, which is total flavour extract of dried and ground chillies which has varied uses in processed food and beverage industries. The fresh oleoresin is a dark colored vicious liquid with characteristic odour anf flavours of the spice.

Chilli is a rich source of red colour. The natural colour extract of chilli are also finding their increased value in place of artificial colors. Its market price based partly on the red colour.

Current procedures for measuring extractable colour (total pigments) in dehydrated capsicums and oleoresins were developed and permitted by the Association of Official Analytical Chemists and the American Spice Trade Association (ASTA).

A number of varieties have been bred in chillies for colour and quality (Derera, 2000). Relatively little information is available on the biochemical constituents of chilli fruits. Therefore, in our study it was aimed to generate information on the important biochemical constituents and fruit quality parameters of chilli cultivars.

\section{Materials and Methods}

\section{Plant material}

Eight genotypes (IS-261, IS-262, IS-267, ML342, PC-408, PL-412, Sel-468 and US-501) of Capsicum annuum L. along with two checks (Punjab Sindhuri and Punjab Tej) were selected for study. Nursery was raised during 1st week of October, 2016 and transplanting was done on 10 November, 2016 for early season crop. Second sowing was done during 1st week of November, 2016 and transplanting was done on 28 February, 2017.

Different genotypes were grown in a completely randomized block design with three replications under field conditions. There were 10 plants per treatment per replication and observations were recorded from 5 representative plants. The observations on yield attributes and fruit quality parameters were recorded after first harvesting.

\section{Yield and yield attributes}

\section{Pollen viability}

To analyze pollen viability, flowers of at least three different plants of each genotype were collected. By using aceto-carmine staining procedure pollens were analyzed for viability.

For each plant three slides were prepared. Forceps and needles were used to open anthers to allow extraction. Subsequently they were transferred on to a glass slide, after adding a drop of aceto-carmine stain. Cover slips were placed on slides gently.

These were then observed under a Leica Bright Field Research microscope fitted with digital camera and computer imaging systems using software NIS Elements F 3.0. For each slide ten fields were spotted under the $10 \mathrm{X}$ objective.

Pollens grains which are darkly stained were recorded as viable and unstained or very lightly stained pollens were considered as non-viable. 
Pollen viability was expressed as percentage pollen viability. Following formula was used to calculate pollen viability:-

Pollen viability $\%=$

Total viable pollen in three microscope fields

Total pollen in three microscope fields

\section{Fruit set (\%)}

Ten flowers from five representative plants were tagged. The tagged fruits of each genotype were harvested at an interval of thirty days and percentage of these harvested fruits was calculated.

\section{Total fruit yield/ plant $(\mathrm{Kg})$}

All the fruits of five plants were collected separately and weighed. The fruit yield was expressed in $\mathrm{kg} /$ plant.

\section{Pericarp thickness (mm)}

All fruits of five plants were collected; Pericarp thickness per fruit was measured with digital vernier caliper and recorded in $\mathrm{mm}$.

\section{Average fruit weight (g)}

Fruits of each cultivar were harvested. The average fruit weight of collected five fruits was expressed in gram $(\mathrm{g})$.

\section{Average fruit length $(\mathrm{cm})$}

Five fruits from five plants of each genotype were selected after harvesting and cut into half. The length was measured with centimeter scale and average was recorded.

\section{Average fruit width (cm)}

Five fruits from five plants of each genotype were selected after harvesting and cut into two half (length wise). The width from widest point was measured with centimeter scale and average was recorded.

\section{Fruit quality parameters}

\section{Capsaicin in powder (\%) (Bajaj and Kaur, 1979)}

\section{Estimation}

In volumetric flask $0.5 \mathrm{~g}$ dried chili powder was taken and ethyl acetate was added to make volume of $25 \mathrm{ml}$. It was shaken thoroughly and then kept for 24 hours in dark at room temperature. After that $2 \mathrm{ml}$ of extract was passed from basic alumina column. Size of column was $10 \times 0.9 \mathrm{~cm}$. at the base of the column, glass wool was added and then $1.5 \mathrm{~g}$ active aluminium oxide was added and finally $1 \mathrm{~cm}$ of layer of sodium sulphate was placed at the top. After the basic alumina column, 2 $\mathrm{ml}$ of extract was added from the top, column was washed three times with the $5 \mathrm{ml}$ of acetone: methanol: water (75:25:1). Total volume was made to $50 \mathrm{ml}$ of stock solution. $10 \mathrm{ml}$ of aliquot was taken and evaporated to dryness at room temperature. After the evaporation was completed, $0.5 \mathrm{ml}$ of Folin and ciocalteu 15 phenol (FC) reagent and 6.5 $\mathrm{ml}$ of distilled water was added or allowed to stand for three minutes. Then one $\mathrm{ml}$ of sodium carbonate solution was added and finally distilled water was added to make final volume upto $10 \mathrm{ml}$ in volumetric flask. The optical density was recorded after one hour at $760 \mathrm{~nm}$.

\section{Coloring matter in powder (ASTA)} (Rosebrook et al., 1968)

\section{Estimation}

Powdered sample $(25 \mathrm{mg})$ was taken and a volume of $100 \mathrm{ml}$ made in volumetric flask with acetone. 
The sample was kept in dark for 4 hours and color intensity was measured at $460 \mathrm{~nm}$.

Coloring matter (ASTA units $)=\frac{\text { Optical density X } 16.4}{\text { Sample taken }(\mathrm{g})}$

\section{Oleoresin content $(\%)$}

(Tandon et al., 1964 and Mathew et al., 1971)

\section{Estimation}

Soxhlet extraction apparatus was used for extraction of chili oleoresin. Forty gram of finely ground chili powder was wrapped in a filter and placed in the extractor. $200 \mathrm{ml}$ of acetone was taken in the flask. The apparatus consisted of distillation, extraction and flask was set up and placed on heater. The distillation part was connected with water connection for continuous running of water. After turning on the heater temperature was adjusted to $5^{\circ} \mathrm{C}$. The heating process was continuous up to 5 hours. The oleoresin accumulated in flask along with acetone from extraction. The acetone was collected in the extractor to use it again. The flask was removed from the apparatus and acetone was further evaporated by slow heating. After complete evaporation of solvent, weight of oleoresin was taken.

$$
\text { Oleoresin content }=\frac{\text { Weight of oleoresin X } 100}{\text { Weight of powder taken }}
$$

\section{Capsaicin in oleoresin $(\%)$}

Capsaicin in oleoresin (\%) was measured by above described method of Bajaj and Kaur (1979) for capsaicin content of chili powder.

\section{Statistical analysis}

The data was analysed through CPCS1 software.

\section{Results and Discussion}

\section{Yield and yield attributes}

Maximum mean fruit set \% was observed in PL-412 followed by IS-267 during both early and timely sown crop (Table 1). In early sown crop, PL-412 showed significantly more fruit set than that observed in both check varieties Punjab Sindhuri and Punjab Tej.Both flower retention and fruit set depend on assimilate supply to the developing reproductive organs. When the availability of assimilates to the developing flower is reduced (e.g. by leaf pruning or shading) abscission is greatly enhanced. Our results corroborate with the findings of Karapanos et al., (2008) in solanaceous crops like tomato, peppers or eggplants and Thuy and Kenji (2015) in sweet pepper.

Maximum mean pollen viability (\%) was shown by genotype IS-267 followed by PL412 in both early and timely sown crop (Table 2). In early sown crop, IS-267 showed $1.87 \%$ and $16.14 \%$ more pollen viability than that observed in both check varieties Punjab Sindhuri and Punjab Tej and it was $17.61 \%$ and $10.80 \%$ more than that observed in flowers of check variety Punjab Tej.When temperatures fall below $10^{\circ} \mathrm{C}$ or rise above $23^{\circ} \mathrm{C}$, at least one of the processes leading to successful fertilization is adversely affected. The reproductive organs of the Solanaceous species are more sensitive than the vegetative organs to high temperature. In pepper, high temperatures during flowering impair pollen germination, pollen tube growth and fertilization, resulting in flower abscission and reduced fruit set. Pollen development and viability is directly related to the availability of carbohydrates because the developing pollen grains accumulate simple sugar. In pepper, heat stress causes a reduction in sucrose translocation from the photosynthesizing leaves to the flower, thus 
negatively affecting its development and fertility. The production and viability of pollen grains are limited either by a possible malfunction of the tapetum, or by impaired carbohydrate metabolism and translocation, leading to a deficient supply of assimilates to the developing pollens (Karapanos et al., 2008). PC-408 and PL-412 showed maximum mean pericarp thickness during both early and timely sown crop (Table 3). Pericarp thickness of these genotypes i.e. PC-408 and PL-412 was significantly more than that observed in check variety Punjab Tej during both early and timely sown crop. Thuy and Kenji (2015) also reported changes in the morphological characteristics of fruits i.e. pericarp thickness, fruit weight and number of seeds got reduced in pepper crop under high temperature conditions.

In early sown crop, maximum mean fruit length was shown by PC-408 followed by ML-342 which was $12.48 \%$ and $2.89 \%$ more than that observed in check variety Punjab Sindhuri and $22.99 \%$ and $12.5 \%$ more than that observed in check variety Punjab Tej (Table 3). In timely sown crop, PL-412 recorded maximum mean fruit length followed by PC-408 and it was significantly $18.51 \%$ and $11.77 \%$ more than that observed in check variety Punjab Sindhuri and $28.66 \%$ and $21.34 \%$ more than that observed in check variety Punjab Tej (Table 3). Exposure to high temperature throughout the fruit development significantly reduced the fruit length ultimately leading to reduction in fruit size in sweet pepper (Thuy and Kenji 2015). Dahal et al., (2006) studied that high temperature and blowing of hot winds during flowering and fruiting period severely affect the fruit set and fruit size in sweet pepper. Kaur (2014) also reported remarkable reduction in fruit size in hot pepper due to high temperature. Reduction in fruit size may be attributed to decreased pollen viability as suggested by Erickson and Markhart (2001).
Maximum mean fruit width was observed in US-501 followed by PL-412 during both early and timely sown crop (Table 3 ). Reduction in fruit width due to high temperature has also been reported by Saha et al., (2010) in sweet pepper and Kaur (2014) in hot pepper. Thuy and Kenji (2015) also observed a reduction in fruit width of sweet pepper was reduced under high temperature conditions. In early sown crop, US-501 recorded maximum mean fruit weight followed by IS-262 (Table 3). In timely sown crop, maximum mean fruit weight was shown by US-501 followed by PL-412 (Table 3). Kaur (2014) also reported that high temperature influenced the individual fruit weight in hot pepper. Reduction in fruit weight with increase in temperature was also observed Thuy and Kenji in sweet pepper (2015).

In both early and timely sown crop, maximum capsaicin content in powder and in oleoresin was observed in genotype PL-412 followed by IS-262 (Table 4). While overall maximum capsaicin content in powder (\%) was recorded in both the check varieties Punjab Sindhuri and Punjab Tej. Rehman and Inden (2012) reported that different cultivars have different compatibilities to synthesize capsaicin under different growing environment. The commercial quality of hot peppers is solely determined by amount of capsaicin (hotness) present in them. There concentrations in different capsaicin fruits is regulated by factors such as light intensity, age of fruit and plant's growing temperature (Zahra et al., 2016). In early sown crop, maximum oleoresin content was shown by US-501 followed by IS-267 which was significantly more than both the check varieties Punjab Tej and Punjuab Sindhuri (Table 4). In timely sown crop, genotype PL-412 and IS-267 recorded with maximum oleoresin content (Table 4). PL-412 showed significantly more oleoresin content than both the check varieties Punjab Sindhuri and Punjab Tej. 
Table.1 Fruit set (\%) at different stages of hot pepper genotypes in early and timely sown crop

\begin{tabular}{|c|c|c|c|c|c|c|c|c|c|c|}
\hline \multirow[t]{2}{*}{ Genotypes } & \multicolumn{5}{|c|}{ Early sown crop } & \multicolumn{4}{|c|}{ Timely sown crop } & \multirow[b]{2}{*}{ Mean } \\
\hline & $\begin{array}{c}\text { 100 DAT } \\
\left(15.2^{\circ} \mathrm{C}\right)\end{array}$ & $\begin{array}{l}130 \text { DAT } \\
\left(28.5^{\circ} \mathrm{C}\right)\end{array}$ & $\begin{array}{c}160 \text { DAT } \\
\left(32^{\circ} \mathrm{C}\right)\end{array}$ & $\begin{array}{c}\text { 190 DAT } \\
\left(32.7^{\circ} \mathrm{C}\right)\end{array}$ & Mean & $\begin{array}{l}40 \text { DAT } \\
\left(28.5^{\circ} \mathrm{C}\right)\end{array}$ & $\begin{array}{c}70 \text { DAT } \\
\left(32^{\circ} \mathrm{C}\right)\end{array}$ & $\begin{array}{l}\text { 100 DAT } \\
\left(32.7^{\circ} \mathrm{C}\right)\end{array}$ & $\begin{array}{l}\text { 130 DAT } \\
\left(31.2^{\circ} \mathrm{C}\right)\end{array}$ & \\
\hline IS-261 & 54.67 & 69.00 & 25.00 & 6.63 & 38.83 & 45.00 & 40.00 & 23.00 & 10.44 & 29.61 \\
\hline IS-262 & 45.33 & 50.00 & 25.00 & 3.33 & 30.92 & 48.00 & 44.33 & 23.33 & 10.00 & 31.41 \\
\hline IS-267 & 55.67 & 65.00 & 52.00 & 3.33 & 44.00 & 47.67 & 45.00 & 25.67 & 9.33 & 31.92 \\
\hline ML-342 & 38.00 & 45.00 & 25.00 & 3.33 & 27.83 & 37.67 & 30.00 & 23.11 & 11.66 & 25.61 \\
\hline PC-408 & 46.00 & 50.00 & 20.00 & 0.00 & 29.00 & 42.00 & 35.33 & 26.22 & 9.33 & 28.22 \\
\hline PL-412 & 68.00 & 82.00 & 45.00 & 6.67 & 50.42 & 52.00 & 46.33 & 30.00 & 9.00 & 34.33 \\
\hline Sel-468 & 55.00 & 41.00 & 35.33 & 3.33 & 33.67 & 37.67 & 35.00 & 23.33 & 10.00 & 26.50 \\
\hline US-501 & 37.33 & 46.00 & 25.00 & 0.00 & 27.08 & 30.00 & 25.00 & 25.56 & 10.00 & 22.64 \\
\hline Punjab Tej (Check) & 50.00 & 53.67 & 46.67 & 10.00 & 40.09 & 46.67 & 41.67 & 23.22 & 14.33 & 31.47 \\
\hline Punjab Sindhuri (Check) & 52.00 & 70.00 & 35.00 & 9.33 & 41.59 & 45.00 & 40.00 & 26.11 & 15.00 & 31.53 \\
\hline Mean & 50.20 & 57.17 & 33.40 & 4.60 & & 43.17 & 38.47 & 24.95 & 10.91 & \\
\hline CD $(5 \%)$ & \multicolumn{4}{|c|}{$\mathrm{A}=6.19, \mathrm{~B}=3.92, \mathrm{AB}=12.39$} & & \multicolumn{4}{|c|}{$A=4.09, B=2.68, A B=8.83$} & \\
\hline
\end{tabular}

Table.2 Pollen viability (\%) at different stages of hot pepper genotypes in early and timely sown crop

\begin{tabular}{|c|c|c|c|c|c|c|c|c|c|c|}
\hline \multirow[t]{2}{*}{ Genotypes } & \multicolumn{5}{|c|}{ Early sown crop } & \multicolumn{4}{|c|}{ Timely sown crop } & \multirow[b]{2}{*}{ Mean } \\
\hline & $\begin{array}{c}100 \text { DAT } \\
\left(15.2^{\circ} \mathrm{C}\right)\end{array}$ & $\begin{array}{c}\text { 130 DAT } \\
\left(28.5^{\circ} \mathrm{C}\right)\end{array}$ & $\begin{array}{c}160 \text { DAT } \\
\left(32^{\circ} \mathrm{C}\right)\end{array}$ & $\begin{array}{c}190 \text { DAT } \\
\left(32.7^{\circ} \mathrm{C}\right)\end{array}$ & Mean & $\begin{array}{l}40 \text { DAT } \\
\left(28.5^{\circ} \mathrm{C}\right)\end{array}$ & $\begin{array}{c}70 \text { DAT } \\
\left(32^{\circ} \mathrm{C}\right)\end{array}$ & $\begin{array}{c}\text { 100 DAT } \\
\left(32.7^{\circ} \mathrm{C}\right)\end{array}$ & $\begin{array}{c}\text { 130 DAT } \\
\left(31.2^{\circ} \mathrm{C}\right)\end{array}$ & \\
\hline IS-261 & 45.67 & 78.49 & 23.63 & 13.68 & 40.37 & 67.39 & 58.46 & 20.03 & 12.93 & 39.70 \\
\hline IS-262 & 59.94 & 66.78 & 27.64 & 16.95 & 42.82 & 64.77 & 41.70 & 21.68 & 14.20 & 35.60 \\
\hline IS-267 & 77.65 & 85.33 & 38.16 & 25.16 & 56.57 & 77.72 & 57.28 & 35.16 & 15.25 & 46.35 \\
\hline ML-342 & 47.03 & 77.92 & 25.64 & 15.58 & 41.54 & 71.18 & 48.84 & 33.83 & 10.61 & 41.11 \\
\hline PC-408 & 63.70 & 72.62 & 30.87 & 19.45 & 46.66 & 70.66 & 52.59 & 27.79 & 18.51 & 42.40 \\
\hline PL-412 & 57.18 & 86.58 & 28.86 & 18.71 & 47.83 & 73.12 & 53.62 & 34.84 & 13.02 & 43.65 \\
\hline Sel-468 & 46.91 & 70.64 & 24.67 & 16.25 & 39.62 & 61.25 & 39.38 & 18.27 & 12.49 & 32.90 \\
\hline US-501 & 62.27 & 67.60 & 31.33 & 19.78 & 45.24 & 68.61 & 46.43 & 24.72 & 13.28 & 38.26 \\
\hline Punjab Tej (Check) & 61.45 & 76.23 & 34.24 & 22.94 & 48.71 & 69.69 & 47.08 & 24.86 & 16.01 & 39.41 \\
\hline Punjab Sindhuri (Check) & 71.96 & 88.13 & 36.81 & 25.21 & 55.53 & 80.49 & 57.26 & 35.13 & 18.78 & 47.91 \\
\hline Mean & 59.38 & 77.03 & 30.18 & 19.37 & & 70.49 & 50.26 & 27.63 & 14.51 & \\
\hline CD $(5 \%)$ & \multicolumn{5}{|c|}{$\mathrm{A}=10.24, \mathrm{~B}=6.47, \mathrm{AB}=\mathrm{NS}$} & \multicolumn{5}{|c|}{$\mathrm{A}=3.37, \mathrm{~B}=2.13, \mathrm{AB}=\mathrm{NS}$} \\
\hline
\end{tabular}


Table.3 Pericarp thickness, fruit length, fruit width, fruit weight and total yield of hot pepper genotypes during both early and timely sown

\begin{tabular}{|c|c|c|c|c|c|c|c|c|c|c|}
\hline \multirow[t]{2}{*}{ Genotypes } & \multicolumn{5}{|c|}{ Early sown crop } & \multicolumn{5}{|c|}{ Timely sown crop } \\
\hline & $\begin{array}{l}\text { Pericarp } \\
\text { thickness }\end{array}$ & $\begin{array}{l}\text { Fruit } \\
\text { length }\end{array}$ & $\begin{array}{l}\text { Fruit } \\
\text { width }\end{array}$ & $\begin{array}{c}\text { Fruit } \\
\text { weight }\end{array}$ & $\begin{array}{l}\text { Total } \\
\text { yield }\end{array}$ & $\begin{array}{l}\text { Pericarp } \\
\text { thickness }\end{array}$ & $\begin{array}{l}\text { Fruit } \\
\text { length }\end{array}$ & Fruit width & $\begin{array}{c}\text { Fruit } \\
\text { weight }\end{array}$ & $\begin{array}{l}\text { Total } \\
\text { yield }\end{array}$ \\
\hline IS-261 & 0.82 & 7.43 & 1.05 & 3.57 & 402.32 & 0.71 & 6.23 & 1.02 & 3.08 & 374.37 \\
\hline IS-262 & 0.89 & 6.76 & 1.61 & 3.96 & 475.41 & 0.78 & 6.59 & 1.20 & 3.46 & 388.04 \\
\hline IS-267 & 1.05 & 6.33 & 1.29 & 3.79 & 512.92 & 0.83 & 6.51 & 1.16 & 3.43 & 457.82 \\
\hline ML-342 & 0.99 & 7.83 & 1.20 & 3.00 & 393.92 & 0.94 & 7.05 & 1.14 & 3.18 & 423.88 \\
\hline PC-408 & 1.29 & 8.56 & 1.34 & 3.51 & 476.84 & 1.16 & 7.79 & 1.23 & 3.39 & 453.89 \\
\hline PL-412 & 1.15 & 7.31 & 1.65 & 3.88 & 524.93 & 1.04 & 6.26 & 1.34 & 3.49 & 491.88 \\
\hline Sel-468 & 0.67 & 5.27 & 0.99 & 3.30 & 372.20 & 0.61 & 5.18 & 1.00 & 2.97 & 358.07 \\
\hline US-501 & 0.92 & 6.97 & 1.72 & 4.14 & 411.07 & 0.88 & 6.86 & 1.57 & 3.67 & 364.00 \\
\hline Punjab Tej (Check) & 0.85 & 6.96 & 1.13 & 4.35 & 393.19 & 0.79 & 6.42 & 1.10 & 4.00 & 339.07 \\
\hline Punjab Sindhuri (Check) & 1.66 & 7.61 & 1.73 & 4.85 & 553.77 & 1.33 & 6.97 & 1.44 & 94.78 & 445.81 \\
\hline Mean & 1.03 & 7.10 & 1.37 & 3.84 & 451.66 & 0.91 & 6.59 & 1.22 & 3.54 & 409.68 \\
\hline CD $(5 \%)$ & 0.19 & 1.22 & 0.35 & 1.15 & 0.12 & 0.12 & 1.57 & 0.29 & 0.90 & 0.27 \\
\hline
\end{tabular}

Table.4 Variation in capsaicin (\%), colouring matter in powder (ASTA), oleoresin content and capsaicin in oleoresin (\%) during both early and timely sown crop

\begin{tabular}{|c|c|c|c|c|c|c|c|c|}
\hline \multirow[t]{2}{*}{ Genotypes } & \multicolumn{4}{|c|}{ Early sown crop } & \multicolumn{4}{|c|}{ Timely sown crop } \\
\hline & $\begin{array}{l}\text { Capsaicin in } \\
\text { powder }(\%)\end{array}$ & $\begin{array}{l}\text { Colouring matter } \\
\text { in powder } \\
\text { (ASTA) }\end{array}$ & $\begin{array}{c}\text { Oleoresin } \\
\text { content }(\%)\end{array}$ & $\begin{array}{c}\text { Capsaicin in } \\
\text { oleoresin }\end{array}$ & $\begin{array}{c}\text { Capsaicin } \\
\text { in powder } \\
(\%)\end{array}$ & $\begin{array}{c}\text { Colouring } \\
\text { matter in } \\
\text { powder (ASTA) }\end{array}$ & $\begin{array}{c}\text { Oleoresin } \\
\text { content }(\%)\end{array}$ & $\begin{array}{c}\text { Capsaicin in } \\
\text { oleoresin }\end{array}$ \\
\hline IS-261 & 0.69 & 128.86 & 12.74 & 2.39 & 0.57 & 114.59 & 11.68 & 2.34 \\
\hline IS-262 & 0.71 & 102.15 & 12.76 & 2.55 & 0.65 & 99.32 & 11.76 & 2.49 \\
\hline IS-267 & 0.64 & 164.35 & 13.25 & 2.47 & 0.63 & 136.18 & 11.72 & 2.36 \\
\hline ML-342 & 0.55 & 94.05 & 12.79 & 2.37 & 0.54 & 86.11 & 11.71 & 2.10 \\
\hline PC-408 & 0.19 & 143.90 & 12.91 & 1.23 & 0.18 & 121.24 & 11.70 & 1.17 \\
\hline PL-412 & 0.78 & 162.04 & 13.05 & 2.72 & 0.67 & 133.45 & 12.14 & 2.66 \\
\hline Sel-468 & 0.57 & 77.49 & 11.01 & 2.22 & 0.44 & 66.17 & 11.17 & 2.05 \\
\hline US-501 & 0.49 & 169.06 & 14.46 & 1.82 & 0.46 & 143.77 & 11.49 & 1.63 \\
\hline Punnjab Sindhuri (check) & 0.99 & 98.25 & 12.81 & 2.39 & 0.94 & 92.06 & 11.75 & 2.41 \\
\hline Punjab Tej (check) & 1.29 & 173.07 & 12.87 & 2.76 & 1.24 & 170.30 & 11.88 & 2.74 \\
\hline CD 5\% & 0.07 & 0.46 & 0.24 & 0.22 & 0.03 & 0.71 & 0.18 & 0.26 \\
\hline
\end{tabular}


Similar variation in oleoresin recovery among the cultivars was reported by (Jyothi et al., 2008). Maximum colouring matter (ASTA) was observed in US-501 and IS-267 during both early and timely sown crop (Table 4). These genotypes showed significantly more colouring matter than check variety Punjab Sindhuri in both early and timely sown crop. Color is the main factor of chili peppers that determine their quality and final market price.

Capsaicinoid accumulation is related to a fruit's age, size, and stage of development (Estrada et al., 1997) and is also regulated by a genotype and an environment interaction (Zewdie and Bosland 2000). Notable variations in colour values among the chilli cultivars were reported by Jyothi et al., (2008).

\section{References}

Asati B S and Yadav D S (2004) Diversity of hyorticultural crops in north eastern region. ENVIS Bull Himal Ecol 12: 111.

Bajaj K L and Kaur G (1979) Colorimetric determination of capsaicin in capsicum fruits with the Folin-Ciocalteu reagent. Microchimica Acta 71: 81-86.

Dahal K C, Sharma M D, Dhakal D D and Shakya S M (2006) Evaluation of heat tolerant chilli (Capsicum annuиm L.) genotypes in western terai of Nepal. $J$ Inst Agric Anim Sci 27: 59-64.

Derrera N F (2000) Condiment paprika - A potential new crop. Agric Sci 1: 24-27

Erickson A N, and Markhart A H (2001) Flower Production, Fruit Set and Physiology of Bell Pepper during Elevated Temperature and Vapor Pressure Deficit. J Amer Soc Hort Sci 126: 697-702.

Estarda B, Pomar M, Diaz J, Marino F and Bernal M A (1997) Evaluation of capsaicinoids in Capsicum annuum $\mathrm{L}$. var. annuum.cv. Pardon fruit at different growth stages.Capsicum and Eggplant newsletter 16: 60-63.

Indian Horticulture Database (2011) National Horticulture Board. Aristo printing press, New Delhi, Pp 6-7.

Jyothi K U, Kumari S S, Reddy K V S, Vijayalakshmi T and Reddy P V (2008) Biochemical evaluation of chilli (Capsicum annuum L.) cultivars suitable for export. J Spices Aromat Crops 17: 209-11.

Karapanos I C, Mahmood S and Thanopoulos C (2008) Fruit set in Solanaceous vegetable crops as affected by floral and environmental factors. The European $J$ Plant Sci Biotech 2: 88-105.

Kaur (2014) Physiological and biochemical changes in some thermotolerant and thermosensitive chilli (Capsicum annuum L.) genotypes. M.Sc. Thesis, Punjab Agricultural University, Ludhiana, India.

Mathew A G, Nambudiri E S, Ananthakrishna S M, Krishnamurthi N and Lewis Y S (1971) An improved method for capsaicin in capsicum oleoresin. $L a b$ practice 1: 23-26.

Rahman M J and Inde H (2012) Effect of nutrient solution and temperature on capsaicin content and yield contributing characteristics in six sweet pepper (Capsicum annuum L.) cultivars. $J$ Food Agric Env Year 10: 524-29.

Rose Brook D D, Prozle C C and Barney J E (1968) Improved method for determination of extracable colour in Capsicum species. Assoc official chemists 51: 637-43.

Saha S R, Hossain M M, Rahman M M, Kuo C G and Abdullah S (2010) Effect of high temperature stress on the performance of twelve sweet pepper genotypes. Bangladesh J Agric Res 35: 525-34.

Tandon G L, Dravid S V and Sidappa G S 
(1964) Oleoresin of capsicum (red chilli). Some technological and chemical aspects. J Fruit Sci 29: 1-5.

Thuy T C and Kenji M (2015) Effect of High Temperature on Fruit Productivity and Seed-Set of Sweet Pepper (Capsicum annuum L.) in the Field Condition. $J$ Agri Sci 5: 515-25.

Zahra N, Alim-un-Nisa, Kalim I, Hina S, Javed A, Inam S M, Malik S M and Arshad F (2016) Estimation of capsaicin in different chilli varieties using different Extraction Techniques and HPLC method: A Review. Pak $J$ Food Sci 26: 54-60.

Zewdie Y and Basland P W (2000) Evaluation of genotype, environment and genotype-by environment interaction for capsaicinoids in Capsicum annuum L. Euphytica 111: 185-90.

\section{How to cite this article:}

Khushpreet Kaur Dhaliwal, Navita Ghai and Jindal. S. K. 2020. Variations in Fruit Quality Parameters of Chilli Genotypes during Early and Timely Sown Conditions. Int.J.Curr.Microbiol.App.Sci. 9(06): 2178-2186. doi: https://doi.org/10.20546/ijcmas.2020.906.266 